Supporting Information

\title{
Flexible Materials for High-Resolution 3D Printing of Microfluidic Devices with Integrated Droplet Size Regulation
}

Niclas Weigel, ${ }^{a}$ Max J. Männel ${ }^{\mathrm{a}}$ and Julian Thiele ${ }^{\mathrm{a}^{*}}$

Leibniz-Institut für Polymerforschung Dresden e.V., Hohe Str. 6, 01069 Dresden, Germany

*corresponding author: thiele@ipfdd.de 


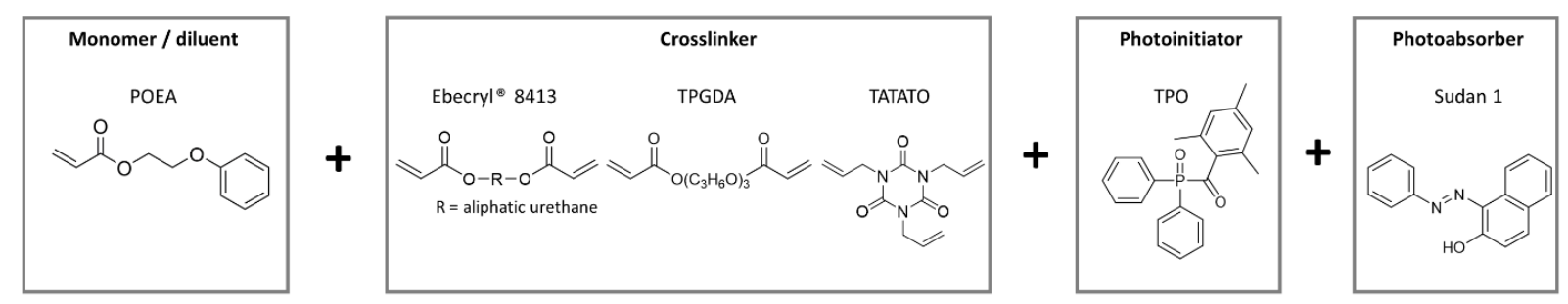

Figure S1. Chemical structures of resin components combined for the design of flexible polymer micromaterials via $\mathrm{P} \mu \mathrm{SL}$.
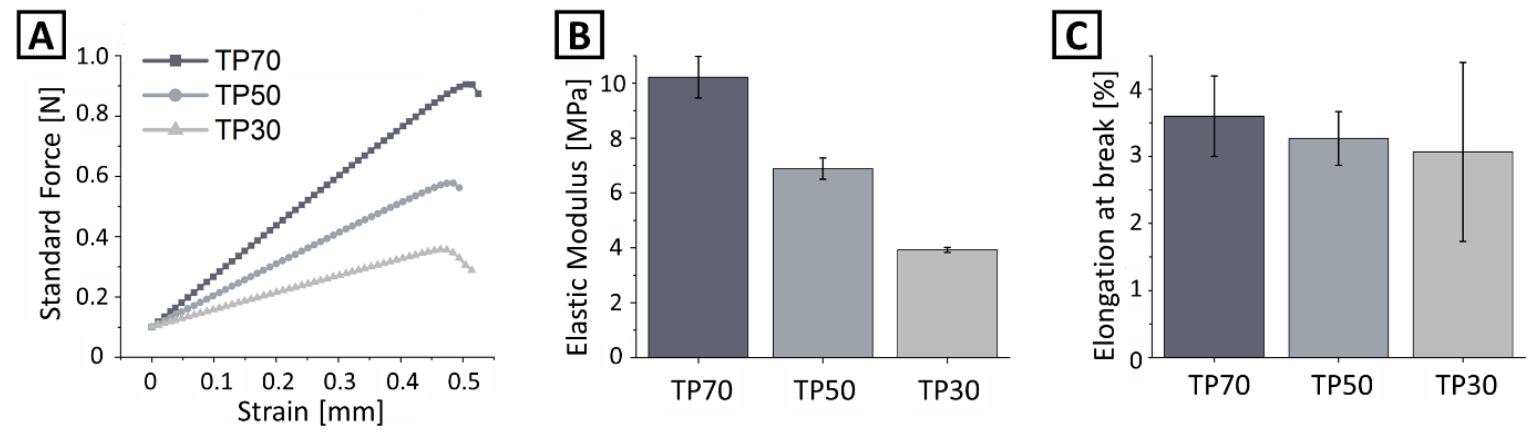

Figure S2. Tensile measurements of 3D-printed dog bone-shaped test objects made from resins with different weight fractions of TPGDA and POEA with $0.25 \%$ (w/w) Sudan 1 and $0.1 \%(\mathrm{w} / \mathrm{w}) \mathrm{TPO}$ conducted at strain rates of $1 \mathrm{~mm} \mathrm{~min}^{-1}$. (A) Force-strain curves with break points of the dog bone-like test objects at $0.89 \pm 0.14 \mathrm{~N}, 0.55 \pm 0.08 \mathrm{~N}$ and $0.32 \pm 0.1 \mathrm{~N}$ for 3Dprinted samples containing 30\% POEA (“TP70”), 50\% POEA (“TP50”) and 70\% POEA (“TP30"), respectively. (B) Elastic moduli calculated to 10.22 $\pm 0.76 \mathrm{MPa}, 6.89 \pm 0.39 \mathrm{MPa}$ and $3.93 \pm 0.09 \mathrm{MPa}$ for 3D-printed samples made from resins with $30 \%, 50 \%$ and $70 \%$ POEA, respectively. (C) Maximum elongations are $3.6 \pm 0.6 \%, 3.3 \pm 0.4 \%$ and $3.1 \pm 1.3 \%$ for 3Dprinted samples prepared from resins with $30 \%, 50 \%$ and $70 \%$ POEA, respectively. 
A

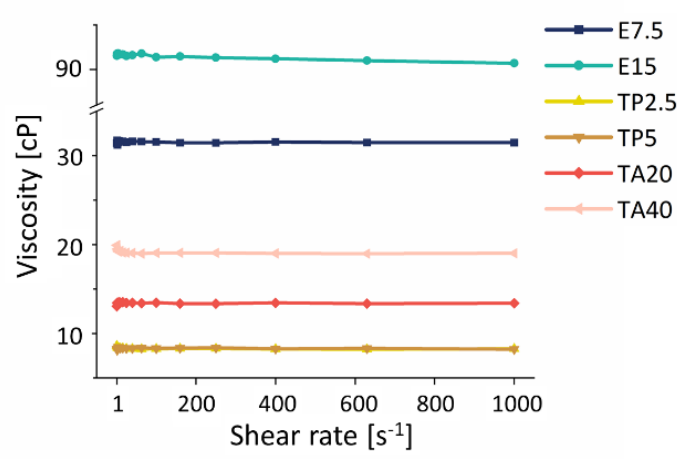

B

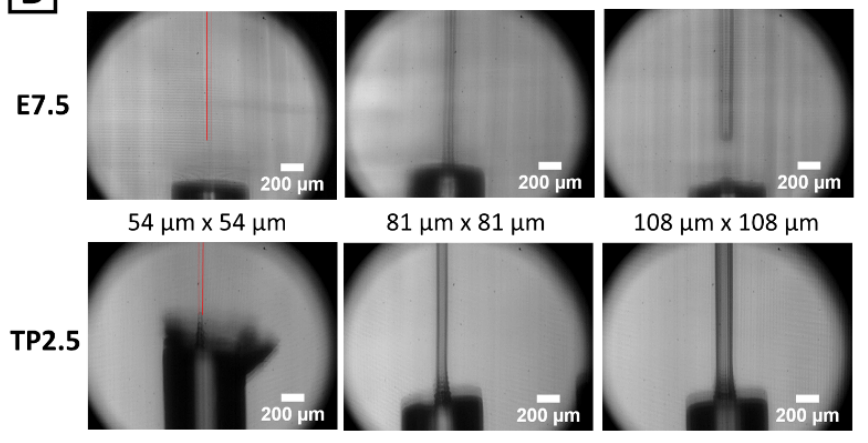

Figure S3. Viscosity measurements of resins employed for 3D printing of microchannels. (A)

Viscosities of the resins E7.5, E15, TP2.5, TP5, TA20 and TA40 measured at $25{ }^{\circ} \mathrm{C}$ with applied shear rates of $1,1.6,2.5,4.0,6.3,10.0,16.0,25.0,40.0,63.0,100,160,250,400,630$ and 1,000 $\mathrm{s}^{-1}$. Average viscosities over all shear rates are $\eta_{\mathrm{E} 7.5}=31.5 \pm 0.1 \mathrm{cP}, \eta_{\mathrm{E} 15}=91.5 \pm 0.3 \mathrm{cP}, \eta_{\mathrm{TP} 2.5}=$ $8.3 \pm 0.1 \mathrm{cP}, \eta_{\mathrm{TP} 5.0}=8.3 \pm 0.1 \mathrm{cP}, \eta_{\mathrm{TA} 20}=13.4 \pm 0.1 \mathrm{cP}$ and $\eta_{\mathrm{TA} 40}=19.2 \pm 0.3 \mathrm{cP}$. (B) 3D-printed void structures with designed dimensions of $54 \mu \mathrm{m} \times 54 \mu \mathrm{m}, 81 \mu \mathrm{m}$ x $81 \mu \mathrm{m}$ and $108 \mu \mathrm{m} \times 108$ $\mu \mathrm{m}$ fabricated from resins E7.5 and TP2.5. Channels with designated dimensions of $54 \mu \mathrm{m} \times 54$ $\mu \mathrm{m}$ are not printed successfully (intended microchannel indicated by red line).

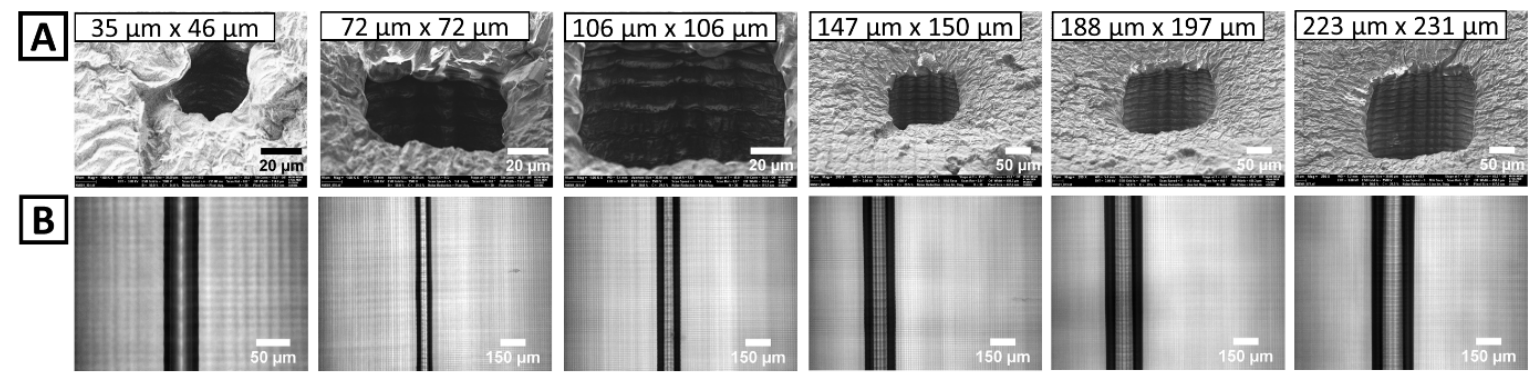

Figure S4. (A) SEM images recorded in a $45^{\circ}$ angle relative to the microchannels with dimensions of 54-by-54 $\mu \mathrm{m}, 81$-by- $81 \mu \mathrm{m}, 108$-by-108 $\mu \mathrm{m}, 135$-by-135 $\mu \mathrm{m}, 162$-by-162 $\mu \mathrm{m}$, and 189-by-189 $\mu \mathrm{m}$. (B) Bright-field microscopy images of microchannels with cross-sections ranging from 54 -by-54 $\mu \mathrm{m}$ to 189 -by-189 $\mu \mathrm{m}$. 


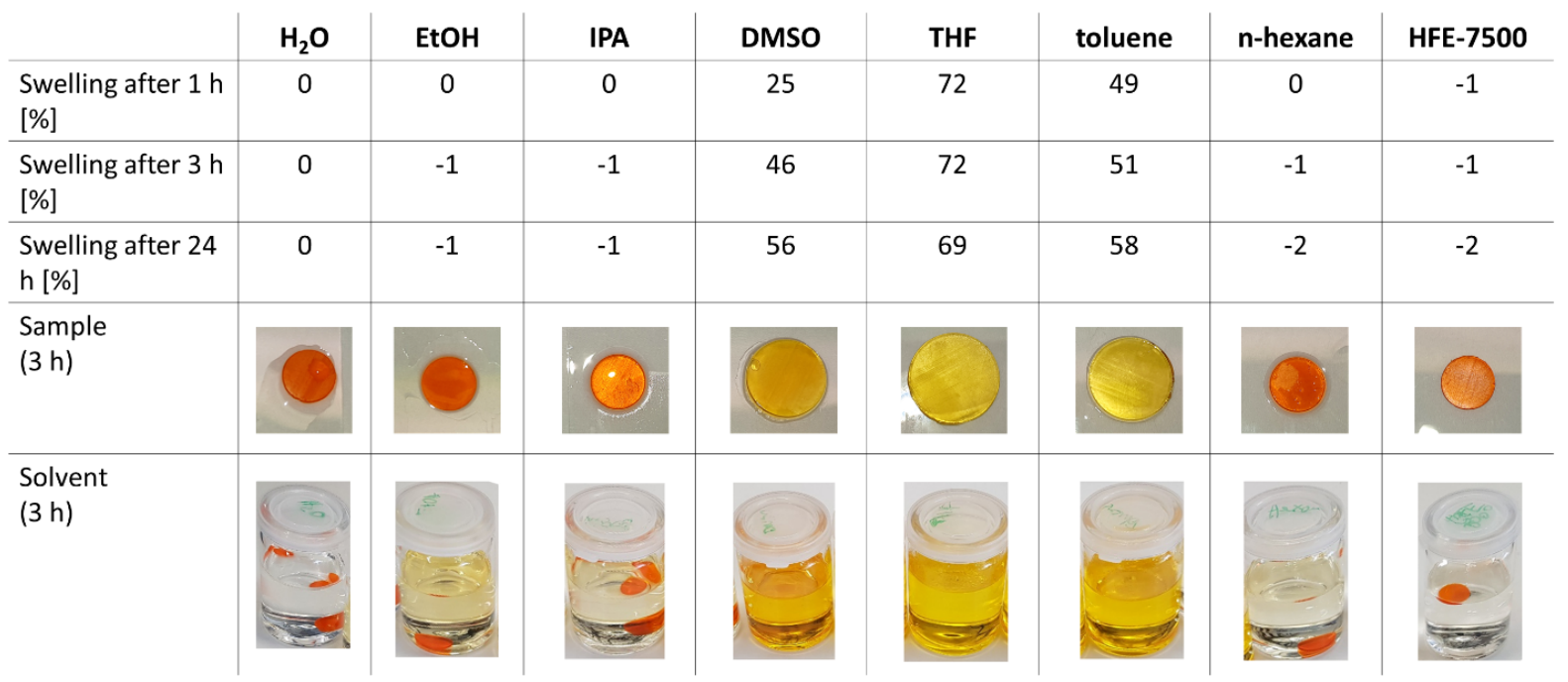

Figure S5. Swelling degree determined by change of diameter of 3D-printed discs $(\mathrm{d}=10 \mathrm{~mm}$, thickness $=1 \mathrm{~mm}$ ) prepared from resin TA20 and kept in different solvents (water, ethanol, isopropyl alcohol, dimethyl sulfoxide, tetrahydrofuran, toluene, n-hexane, HFE 7500 (3M)) for 1 hour, 3 hours and 24 hours, respectively. 
A

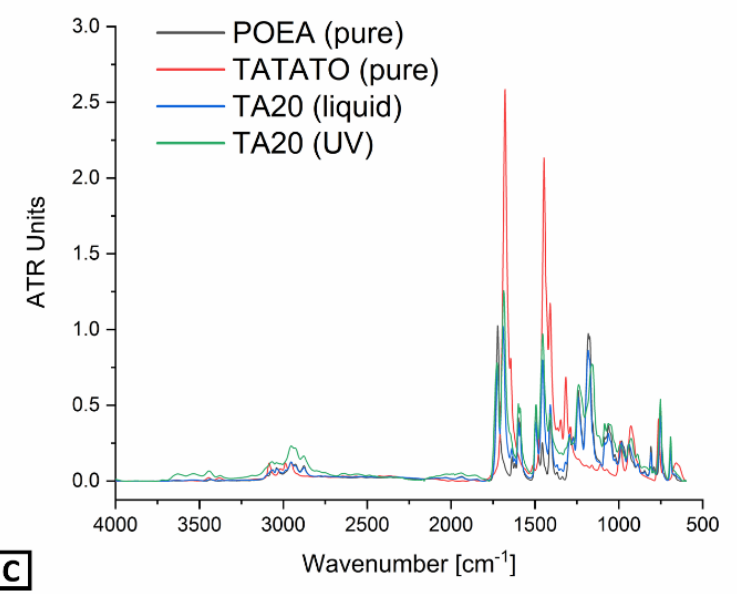

C

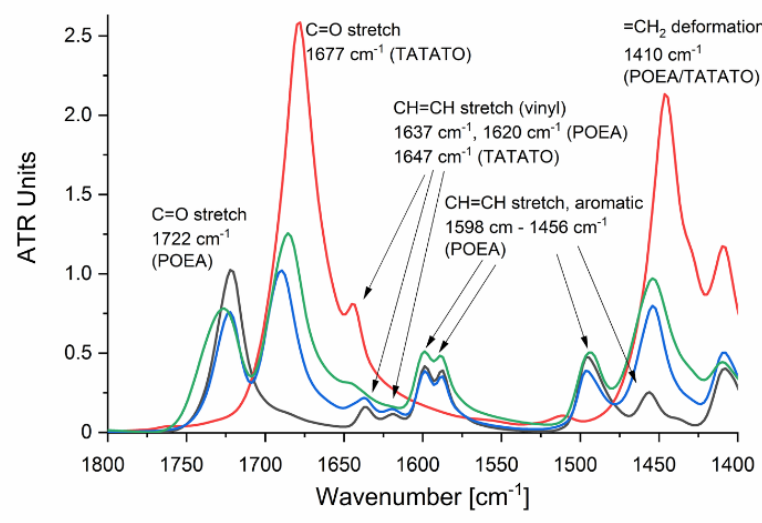

B
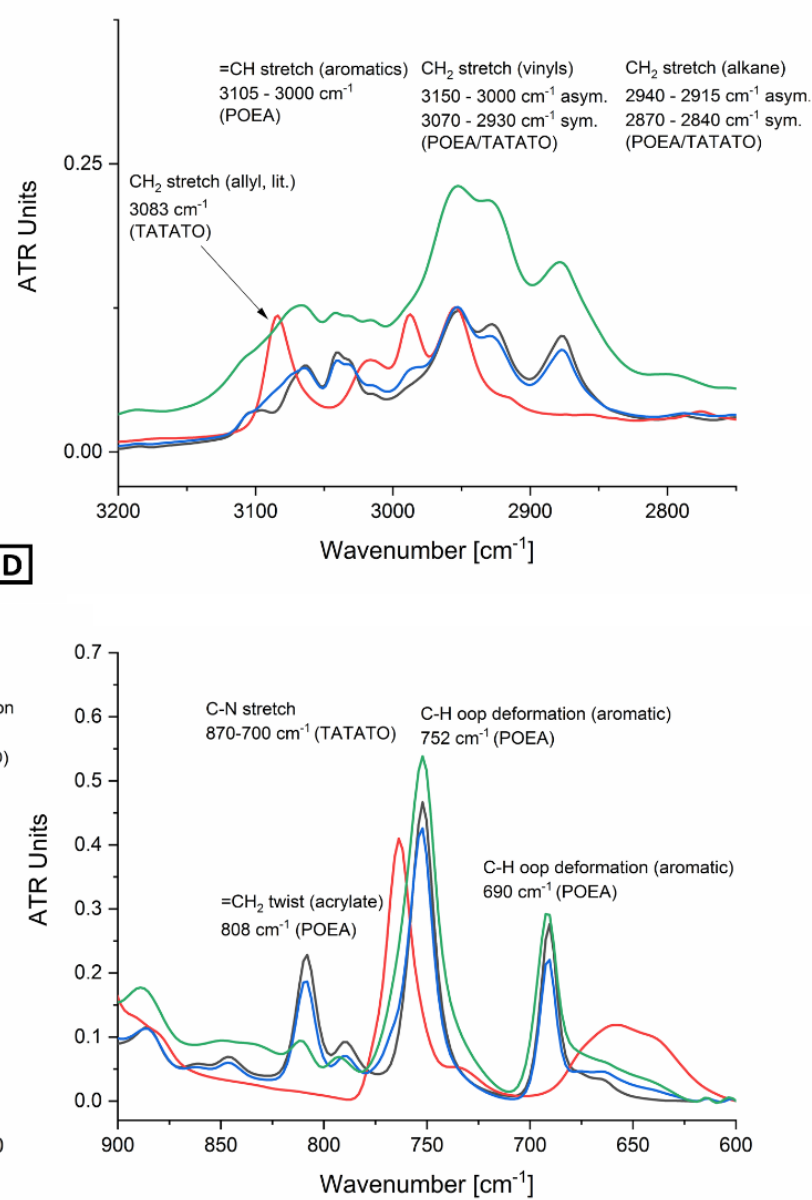

Figure S6. FT-IR spectra of TA20. A) FT-IR spectra of pure POEA, pure TATATO, TA20 in liquid state and a rinsed, polymerized sample of TA20 after 15s UV exposure time taken at wavenumbers from $4000 \mathrm{~cm}^{-1}$ to $600 \mathrm{~cm}^{-1}$. B) Characteristic bands in the region $3200 \mathrm{~cm}^{-1}$ to $2750 \mathrm{~cm}^{-1}$ with the band at $3083 \mathrm{~cm}^{-1}$ being determined to be the $\mathrm{CH}_{2}$ stretch vibration of the allyl group (Ref.). The vibrations of $=\mathrm{CH}$ stretch (aromatics), $\mathrm{CH}_{2}$ stretch (vinyls) and $\mathrm{CH}_{2}$ stretch (alkane, $\mathrm{C}-\mathrm{H}_{2}-\mathrm{C}$ ) are not assigned precisely. C) Characteristic bands in the region 1800 $\mathrm{cm}^{-1}$ to $1400 \mathrm{~cm}^{-1}$ with the characteristic bands of the vinyl groups $(\mathrm{CH}=\mathrm{CH}$ stretch $)$ overlapping in the UV-polymerized sample at $\sim 1647 \mathrm{~cm}^{-1}$ (TATATO) and $\sim 1637 \mathrm{~cm}^{-1}$ (POEA). D) Characteristic bands at wavenumbers from $900 \mathrm{~cm}^{-1}$ to $600 \mathrm{~cm}^{-1}$ with the aromatic out of plane 
deformations visible as well as the $=\mathrm{CH}_{2}$ twist vibration of the acrylate being apparent around $808 \mathrm{~cm}^{-1}$.

\section{A}
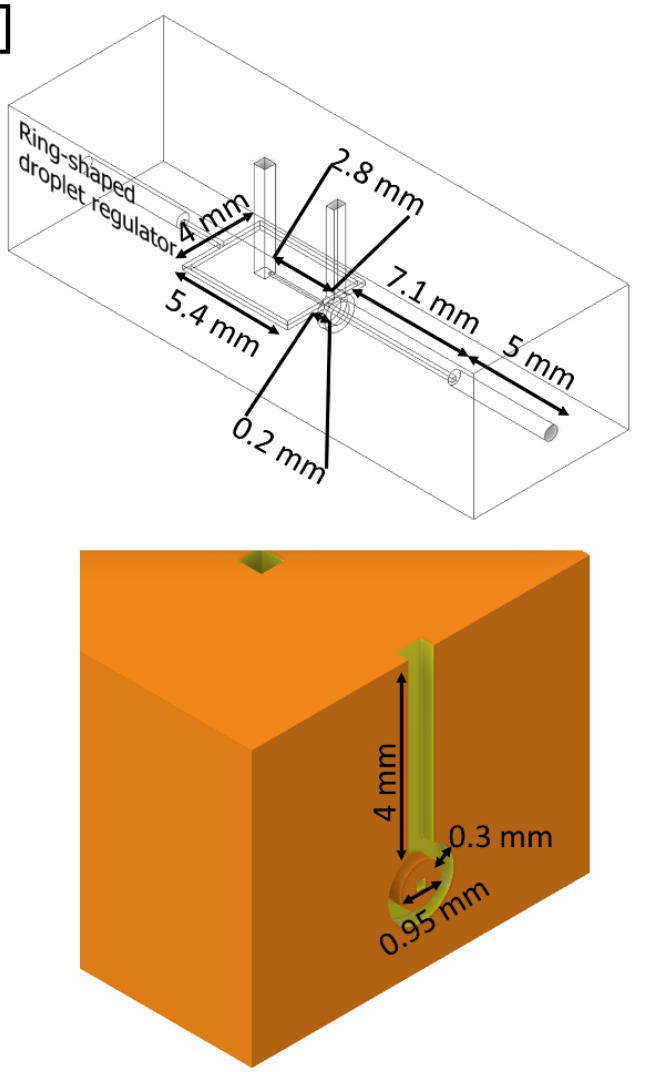

B
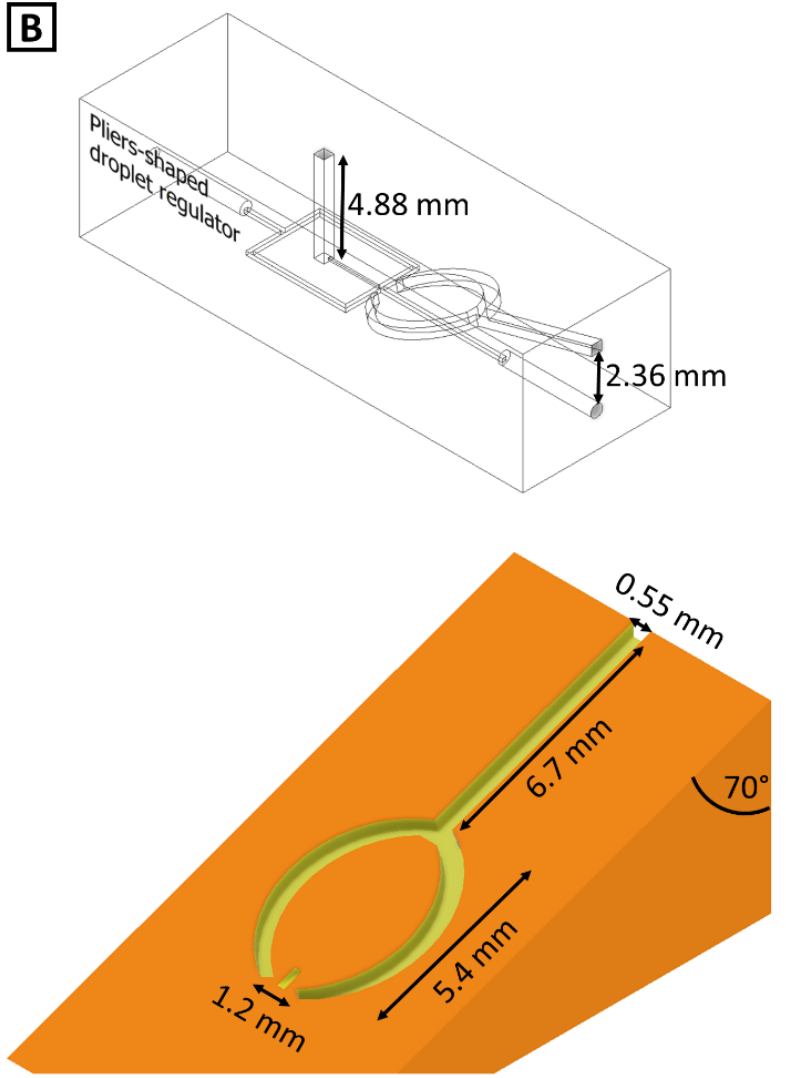

Figure S7. Computer-aided designs (CAD) of microfluidic devices with the integrated droplet regulator units. (A, top) Schematic of microfluidic device with ring-shaped droplet regulator and the respective microchannel, inflow and outflow channel dimensions. (A, bottom) Ring-shaped channel surrounding the droplet-forming microchannel. (B, top) Microfluidic device with pliersshaped droplet regulator with the dimensions of the inflow channel of the dispersed phase and the distance between the regulator's inflow channel and the emulsion's outflow channel. (B, bottom) Droplet size regulator viewed in plane of the pliers-shaped regulator with its corresponding dimensions. 


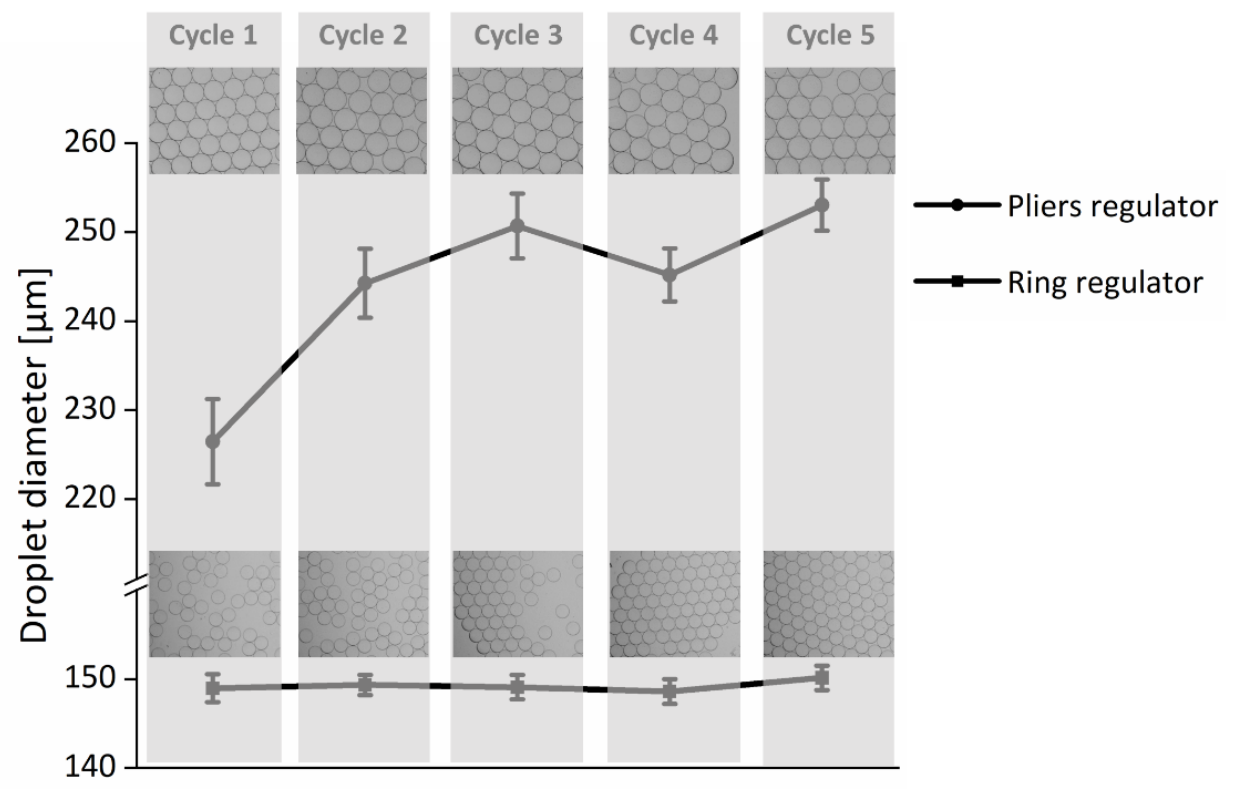

Figure S8. Cycle testing of droplet regulators 3D-printed from resin TA20. (A) For both designs, the ring-shaped and pliers-shaped droplet regulator, cycle tests are carried out to confirm the reproducible production of desired emulsion droplet sizes. For the ring design, 590 $\mathrm{mm}^{3}$ of air volume and for the pliers design $660 \mathrm{~mm}^{3}$ of air volume are repeatedly injected and withdrawn. After each air volume injection, droplet diameters are evaluated. For the ring-shaped droplet size regulator, measured droplet diameters at $\mathrm{V}_{\text {Air }}=590 \mathrm{~mm}^{3}$ are $\mathrm{d}_{\text {Cycle } 1}=149.0 \pm 1.6$ $\mu \mathrm{m}, \mathrm{d}_{\text {Cycle } 2}=149.3 \pm 1.1 \mu \mathrm{m}, \mathrm{d}_{\text {Cycle3 }}=149.1 \pm 1.4 \mu \mathrm{m}, \mathrm{d}_{\text {Cycle } 4}=148.6 \pm 1.4 \mu \mathrm{m}$ and $\mathrm{d}_{\text {Cycle } 5}=$ $150.1 \pm 1.4 \mu \mathrm{m}$. For the pliers-like regulator design, emulsion droplet diameters at $\mathrm{V}_{\text {Air }}=660$ $\mathrm{mm}^{3}$ are $\mathrm{d}_{\text {Cycle } 1}=226.4 \pm 4.8 \mu \mathrm{m}, \mathrm{d}_{\text {Cycle } 2}=244.2 \pm 3.9 \mu \mathrm{m}, \mathrm{d}_{\text {Cycle } 3}=250.7 \pm 3.6 \mu \mathrm{m}, \mathrm{d}_{\text {Cycle } 4}=$ $245.2 \pm 3.0 \mu \mathrm{m}$ and $\mathrm{d}_{\text {Cycle } 5}=253.0 \pm 2.9 \mu \mathrm{m}$. 
A
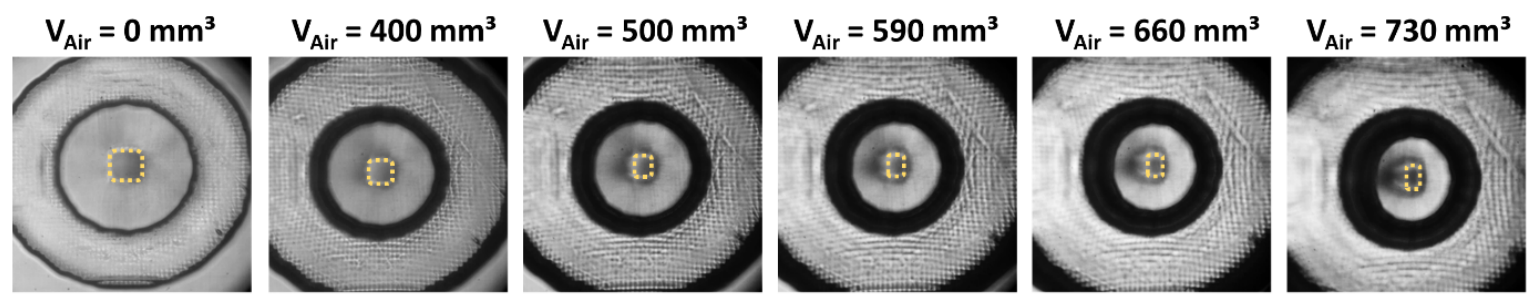

\section{$B$}
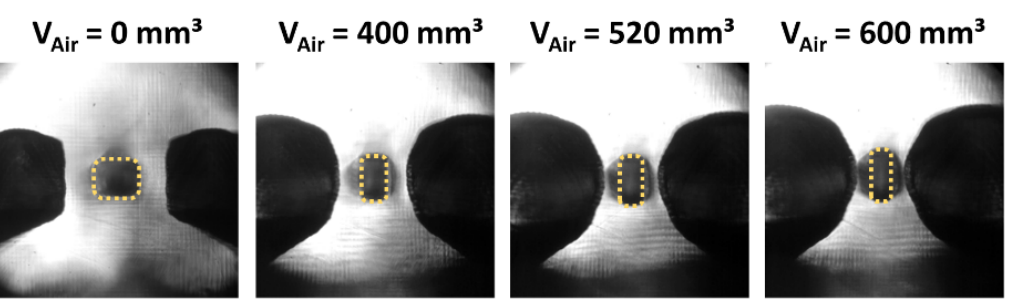

$V_{\text {Air }}=650 \mathrm{~mm}^{3}$

$\mathrm{V}_{\text {Air }}=700 \mathrm{~mm}^{3}$
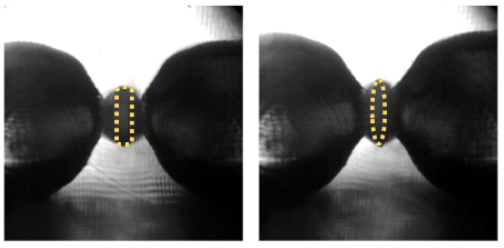

Figure S9. Change of droplet size upon expansion of droplet regulators. (A) Expansion of ring regulator for injected air volumes of $\mathrm{V}_{\text {Air }}=0 \mathrm{~mm}^{3}, \mathrm{~V}_{\text {Air }}=400 \mathrm{~mm}^{3}, \mathrm{~V}_{\text {Air }}=500 \mathrm{~mm}^{3}, \mathrm{~V}_{\text {Air }}=590$ $\mathrm{mm}^{3}, \mathrm{~V}_{\mathrm{Air}}=660 \mathrm{~mm}^{3}$ and $\mathrm{V}_{\text {Air }}=730 \mathrm{~mm}^{3}$. Yellow-dashed lines indicate channel dimensions visible by the transmitting light through the channel. (B) Expansion of ring regulator for injected air volumes of $\mathrm{V}_{\text {Air }}=0 \mathrm{~mm}^{3}, \mathrm{~V}_{\text {Air }}=400 \mathrm{~mm}^{3}, \mathrm{~V}_{\text {Air }}=520 \mathrm{~mm}^{3}, \mathrm{~V}_{\text {Air }}=600 \mathrm{~mm}^{3}, \mathrm{~V}_{\text {Air }}=650 \mathrm{~mm}^{3}$ and $\mathrm{V}_{\text {Air }}=700 \mathrm{~mm}^{3}$. Yellow-dashed lines indicate the channel dimensions. Resulting regulator expansions and corresponding channel dimensions may not be identical with the injected air volumes in Fig. 6 and Fig. 7 due to design changes and small variations in tubing length connecting the syringe pump and air reservoir, respectively, and the droplet regulator. 
Table S-1. Comparison of recent publications on 3D printing microfluidic flow cells focusing on minimum internal feature size fabricated by projection $\mu$-stereolithography (P $\mu \mathrm{SL})$ / digital light processing.

\begin{tabular}{|c|c|c|c|}
\hline Reference & Year & Material & $\begin{array}{l}\text { Resolution/Internal } \\
\text { channel sizes }\end{array}$ \\
\hline${\text { Gong et } \mathrm{al}^{1}}^{1}$ & 2015 & PEGDA & $60 \mu \mathrm{m} \times 108 \mu \mathrm{m}$ \\
\hline Gong et $\mathrm{al}^{2}$ & 2017 & PEGDA & $18 \mu \mathrm{m} \times 20 \mu \mathrm{m}$ \\
\hline Folch et $\mathrm{al}^{3}$ & 2018 & $\begin{array}{l}\text { Methacryloxypropyl- } \\
\text { PDMS }\end{array}$ & $500 \mu \mathrm{m}$ \\
\hline Männel et $\mathrm{al}^{4}$ & 2019 & $\mathrm{R} 11$ & $75 \mu \mathrm{m}$ \\
\hline Gonzalez et $\mathrm{al}^{5}$ & 2020 & Acrylate-PDMS & $400 \mu \mathrm{m}$ \\
\hline Wang et $\mathrm{al}^{6}$ & 2020 & PEGDA & $30 \mu \mathrm{m}$ \\
\hline $\begin{array}{l}\text { Weigel, Männel, } \\
\text { Thiele }\end{array}$ & 2021 & POEA/TATATO & $\sim 35 \mu \mathrm{m} \times 46 \mu \mathrm{m}$ \\
\hline
\end{tabular}

\section{References for table S1}

1. Gong, H.; Beauchamp, M.; Perry, S.; Woolley, A. T.; Nordin, G. P., Optical Approach to Resin Formulation for 3D printed Microfluidics. RSC Advances 2015, 5 (129), 106621-106632. 2. Gong, H.; Bickham, B. P.; Woolley, A. T.; Nordin, G. P., Custom 3D Printer and Resin for $18 \mu \mathrm{m} \times 20 \mu \mathrm{m}$ Microfluidic Flow Channels. Lab on a Chip 2017, 17 (17), 2899-2909. 3. Bhattacharjee, N.; Parra-Cabrera, C.; Kim, Y. T.; Kuo, A. P.; Folch, A., DesktopStereolithography 3D-Printing of a Poly(dimethylsiloxane)-Based Material with Sylgard-184 Properties. Advanced Materials 2018, 30 (22), 1800001.

4. Männel, M. J.; Selzer, L.; Bernhardt, R.; Thiele, J., Optimizing Process Parameters in Commercial Micro-Stereolithography for Forming Emulsions and Polymer Microparticles in Nonplanar Microfluidic Devices. Advanced Materials Technologies 2019, 4 (1), 1800408. 5. Gonzalez, G.; Chiappone, A.; Dietliker, K.; Pirri, C. F.; Roppolo, I., Fabrication and Functionalization of 3D Printed Polydimethylsiloxane-Based Microfluidic Devices Obtained through Digital Light Processing. Advanced Materials Technologies 2020, 5 (9), 2000374. 6. Wang, Y.; Wang, Y.; Mei, D., Scalable Printing of Bionic Multiscale Channel Networks Through Digital Light Processing-Based Three-Dimensional Printing Process. 3D Printing and Additive Manufacturing 2020, 7. 